\title{
ONLINE MEDIA ACCEPTANCE AND USE IN INDONESIAN RURAL AREA: PRIMARY SCHOOLS TEACHER'S PERSPECTIVE
}

\author{
Herli Salim $^{1}, \&$ Muhammad Hanif ${ }^{2}$ \\ ${ }^{1}$ Prodi PGSD Kampus UPI di Serang, Universitas Pendidikan Indonesia \\ ${ }^{2}$ Prodi PGSD Kampus UPI di Serang, Universitas Pendidikan Indonesia \\ herlisalim@upi.edu ${ }^{1}$,muhammadhanif@upi.edu ${ }^{2}$
}

\begin{abstract}
This exploratory study aimed to describe the current teachers' acceptance and use of online media for primary school in rural areas.The study used interview and survey as data collection methods which were divided into two focus questions. This study adopted six indicators of Technology Acceptance Model by Davis to measure the participants' experience on using online learning media. The participants consisted of 30 teachers from four private and government schools in Indonesia. The data collection methods for this study included a survey and open-ended face-to-face interviews in the sense of triangulation for validity and reliability. This study explored the current condition qualitatively, classified each indicator based on interview data reduction and analyzed descriptively. The study found the teachers' accept using online media in integrated learning but they cannot use it because of the lack facilities and the schools' rules of using online media. The external variables, perceived ease of use, perceived usefulness and attitudes of the teacher showed the positive acceptance for online learning implementation. Unfortunately, they did not find support to enhance their lack of behavioural intention use and actual use during the teaching practice. The study proposes the development of a supportive environment and facilities to support factual use of online learning in rural areas. This study recognises that online learning was perceived as important to maximize potential of teaching in rural areas. It also highlighted that teachers in rural areas have behavioural intention to implement online learning although in limitation. This study presented significant gap between teachers' technology acceptance and usage in rural area to be highlighted toward the affordable online learning in the future
\end{abstract}

Keywords: elementary school; teachers' acceptance; teachers' use; online media; technology

\begin{abstract}
Abstrak: Penelitian eksploratif ini bertujuan untuk mendeskripsikan penerimaan dan penggunaan media online oleh guru saat ini untuk sekolah dasar di pedesaan. Penelitian ini menggunakan metode pengumpulan data wawancara dan survei yang terbagi menjadi dua pertanyaan fokus. Penelitian ini mengadopsi enam indikator Technology Acceptance Model untuk mengukur pengalaman peserta dalam menggunakan media pembelajaran online. Pesertanya terdiri dari 30 guru dari empat sekolah swasta dan negeri di Indonesia. Studi ini menggali secara kualitatif kondisi terkini dan mengklasifikasikan setiap indikator berdasarkan reduksi data wawancara kemudian dianalisis secara deskriptif. Hasil penelitian menemukan penerimaan guru menggunakan media online dalam pembelajaran terpadu tetapi tidak dapat digunakan karena kurangnya fasilitas dan aturan sekolah dalam menggunakan media online. Variabel eksternal, persepsi kemudahan penggunaan, persepsi kegunaan dan sikap guru menunjukkan penerimaan yang positif terhadap pelaksanaan pembelajaran online. Sayangnya, mereka tidak menemukan dukungan untuk meningkatkan kurangnya penggunaan niat perilaku dan penggunaan aktual selama praktik mengajar. Studi ini mengusulkan pengembangan lingkungan dan fasilitas yang mendukung untuk mendukung penggunaan faktual pembelajaran online di daerah pedesaan. Studi ini mengakui bahwa pembelajaran online dianggap penting untuk memaksimalkan potensi pengajaran di pedesaan. Ditegaskan pula bahwa guru di pedesaan memiliki niat berperilaku untuk melaksanakan pembelajaran online meskipun dalam batasan. Studi ini menunjukkan kesenjangan yang signifikan antara penerimaan dan penggunaan teknologi guru di daerah pedesaan untuk disorot ke arah pembelajaran online yang terjangkau di masa depan
\end{abstract}

Kata kunci: sekolah dasar; penerimaan guru; penggunaan oleh guru; media online; teknologi 


\section{INTRODUCTION}

The current generation has grown up with a fully functioning Internet, social media, and information due to the rapid development of digital technology. That high usage of digital technology forces schools to employ technology (Simuforosa, 2013). In developing countries, it may not run well since the lack of technology integration within schools. Some schools currently support various online learning assisted by technology both fully and partly instruction. Although many studies have shown that technology integration within the classroom potentially increases educational productivity, some challenges are also faced during implementation.

It is recognized that the adoption of technologies reinforce educational inequality. Better technology access and acceptance can lead to heightened educational inclusion as well as to further discrimination of already rural area. Socio-demographic characteristics are associated with the inequal technology implementation. Among the demographic issues are the lack of educational and technological infrastructure, skilled teachers, negative attitudes towards online learning, social and cultural restrictions (Pimmer et al., 2016). A similar case also happened in school context. So, it is important to investigate the current situation in schools in those disadvantaged areas.

The use of technology is becoming more sophisticated in the 21 st century. There are many kinds of technology that can support human life, especially in teaching and learning activities. Technology in teaching and learning also dominates education. Technology in learning implementation is developed since teachers are aware of their potential and to support them in curricula, teaching guidelines, and teacher training (Softić, 2015). Regarding the technology development, there are various kinds of media for involving students' language learning to bring a new atmosphere for teachers because this program is one of new innovations in learning. Language teachers face the atmosphere that will create a new way in teaching, as Babic (2012) stated teachers who create virtual learning environments have relationship to the instructional design principles and transform the way of their teaching. Online media platforms are believed as one of technology that supports teaching learning activity.

Online media is a web-based system that is believed to be able to support teaching and learning activities. It is a system designed to aid teachers to deliver learning content to students, which can also be used to enhance conventional classroom or distance learning (Chipps, et al., 2015). Online media platforms enable teachers and students to connect learning goals with student portfolios, online assessments, and accessible resources in digital formats (Faizi, ElAfia, \& Chiheb, 2013).

Online media platforms have many advantages for both students and teachers. Dabbagh \& Bannan-Ritland identified the most common features consisted of four features, such as content creation, communication, assessment and administration (Kats, 2010). Based on the features, the function of an online media platform can provide more efficient ways of teaching, has economic scale for teaching and technology support, has more flexibility for students and enriches students learning experiences (Chipps, et al., 2015). Besides the simplicity, the other functions, for students, it is as a tool to get exercise from teacher that they do not get in the classroom. For teachers as the instructors, they have access to the system, which enable them to host a range of online resources and tools such as tutorials, content or skills-related activities, quizzes, message boards, chats, discussion lists, tracking of students' progress, course content pages and systems for collecting and collating students' marks (Sayfouri, 2016).

\section{Teaching and Learning in $21^{\text {th }}$ Century}

Technological transformations must be designed to meet the needs of the widest spectrum of learners in the 21st century (Malik, 2018). Teachers can support students developing essential skills for the 21century through discover which approaches help them learn most effectively (Scott, 2015). 
Language learning is a learning activity that can be helped by technology in this case is computer technology. As mentioned by Brown (2000) the benefits of including a computer component in language instructions including, (a) multimodal practice with feedback, (b) individualization in a large class (Sadeghi \& Dousti, 2013), (c) par and small group work on project either collaboratively or competitively, (d) variety in the resources available and learning style used, (e) exploratory learning with large amounts of language data and (f) real-life skill-building in computer use

In the development of technology, language learning ability is enhanced. It is because there are many supported web designs that promote students actively involved in learning, when assignments reflect real-life contexts and experiences; and when critical thinking or deep learning is promoted through applied and reflective activities (Aljaraideh \& Bataineh, 2019). To engage learning quality, the situation of learning should be more active. In this era, students are active learners rather than spectators. They view themselves as participants in creating information and new ideas (Redecker \& Punie, 2013; Scott, 2015). To reach active learning, there are many multimedia advertisements in this century which are promoted. The multimedia may vary whether they are in the form of audio, visual, audio visual, integrated to internet and much more, as stated by Brown (2000) that the other types of technology aids are commonly available to a language teacher today, such as commercially produced audiotapes and videotapes, self-made audiotapes and videotapes and overhead projection which nowadays being transformed but still in the same functions.

In this century, online learning is becoming worldwide to use as media to support learning. Eaton (2010) mentioned the technologies to support students learning may be synchronous (done in real time), and asynchronous (not done in real time). Online learning thrusts learners into a learning experience, increasing engagement and providing activities that actively engage learners to analyze, synthesize, and evaluate information while constructing knowledge (Darling-Hammond, et al., 2020).

\section{Information Communication Technology (ICT) in Elementary School}

In the modern era, technology can be used to support teaching and learning. Technology involves the generation of knowledge and processes to develop systems that solve problems and extend human capabilities (Garcia, Abrego, \& Jauregui, 2019). Information and Communication Technology (ICT) has become a major focus of interest in the educational field because it is viewed with much optimism and much energy goes into its implementation in schools (Asiri, et al., 2012). Besides the cause of the focus of ICT is when education is viewed as a way to guide people into the information age, there is a need to transform education to meet the new challenges facing society (Player-Koro, 2012).

Related to the change of education view from conventional to ICT, students will be more active, can learn at and outside school, have much teamwork, ask many questions, can find answer to questions and have high interest in learning; besides that, for teachers, ICT can help them to guide students find appropriate instructional path, guide students having independent learning (Teeroovengadum, Heeraman, \& Jugurnath, 2017), help students to evaluate students' progress, put students to the high communication skill.

The form of ICT in learning can be called as multimedia for learning that relates with students' cognitive and pedagogical issues (Gellerstedt, Babaheidari, \& Svensson, 2018). Mayer and Moreno (2007) stated that the multimedia learning engages three important cognitive processes of selecting, organizing and integrating. Many researchers argued that teachers' role in elementary school learning would be beneficial. With this respect, teachers' technological beliefs affect their use of ICT in the classroom (Varol, 2013).

Online learning is important for building a technologically literate workforce as well as for meeting society's continuous need for rapid life-long learning delivered in increasingly more convenient forms (Basak, Wotto, \& Belanger, 2018). While not a direct consequence of its 
implementation, meaningful online learning in classroom instruction is indeed important as to boost student achievement and learning (Machado \& Chung, 2015).

\section{Technology Acceptance Model (TAM)}

Technology Acceptance Model (TAM) is a theory developed by Davis et al (1989) that explained the usage of IT. He mentioned the perceived usefulness and perceived ease of use represented the beliefs that lead to IT acceptance (Amin, Rezaei, \& Abolghasemi, 2014). The perceived usefulness is an aspect that someone believes that a user will enhance their job achievement. Meanwhile, for perceived ease of use, is an aspect that someone believes in using a specific system intensively shows the ability toward a system (Al-Suqri, 2014).

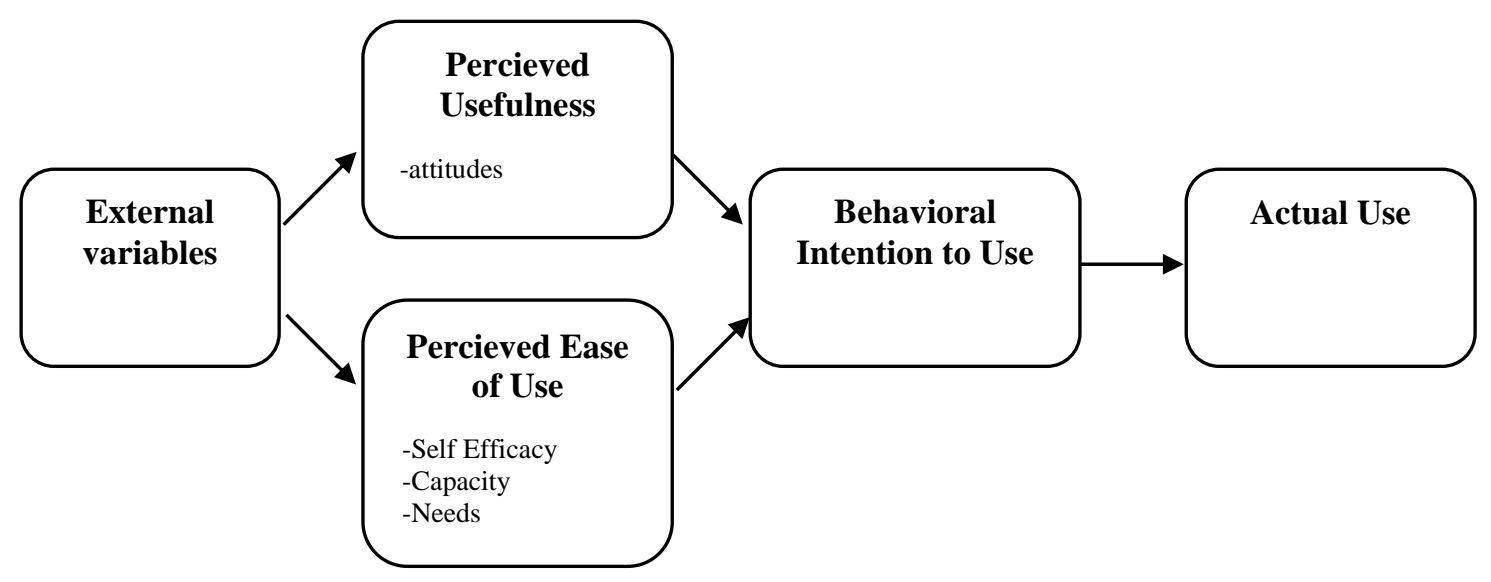

Figure 1. Technology Acceptance Model (TAM)

Behavioral intention to use is determined by the perceived usefulness and perceived ease of use. It is a behavior that drifts someone to use a technology. Davis (1993) stated someone intention of using technology is predicted by his or her awareness of using technology such as eager to add specific supporting equipment (Weng, et al., 2018), motivation to keep using the technology and the willingness to motivate others (Kanchanatanee, Suwanno, \& Jarenvongrayab, 2014). Further, dependent variable of actual use is a real condition of the user (Figure 1). It is an aspect of someone's satisfaction if he or she believes it is easy to be used and could develop productivity in the real context. This condition is determined by the amount of time used in exploring the technology and the intensity of using it.

In the context of online learning and the school's factors, principals in the school led the teachers to participate in online learning activities. All user acceptance behaviour can be explained by TAM and need a modification and adjustment to additional subjective norms and variables (Juhary, 2014; Jeffrey, 2015; Cheng, at al., 2013). To increase the validity of TAM, this research discussed the nature and specific influences of administration at schools and online learning context factors that may alter the principal acceptance (Teo \& Milutinovic, 2015). The TAM validity and reliability has been measured in numerous studies and indicate a reliable way to measure technology use and its influences.

\section{METHODS}

\section{Research Design}

This study investigated elementary teachers' acceptance and factual use of online media in teaching in rural areas. The study used exploratory study to gain greater insight into the interactions between teachers and online media. The target population of the teachers was chosen to build the existing studies that sampled the same population (Holden, Ozok, \& Rada, 
2008). A descriptive explanation was selected because it is open ended and allows for an indepth understanding of what is being studied (Creswell, 2013).

\section{Data collection}

The instruments of this study were interviews to investigate the teachers' current and ideal usage as well as their attitudes of online learning instructional technologies. The instrument used the theory from Technology Acceptance Model (TAM), consisting of four sections consisting of external variables, perceived usefulness, perceived ease of use, behavioral intention to use, and actual use. The items were developed to analyse the teachers' thoughts about using online learning in their practical life. The question consists of 47 main questions, which were adopted by researchers from some review of literature and experts' opinions (AlSuqri, 2014; Juhary, 2014). Thus developed by improving questions to collect deeper understanding about the items administered (Table 1). Multiple methods were used to avow an in-depth investigation. The data collection methods for this study included a survey and openended face-to-face interviews in the sense of triangulation for validity and reliability. The interview and survey were collected during the 2018-2019 academic year.

Tabel 1. Variables, indicator and item of TAM used

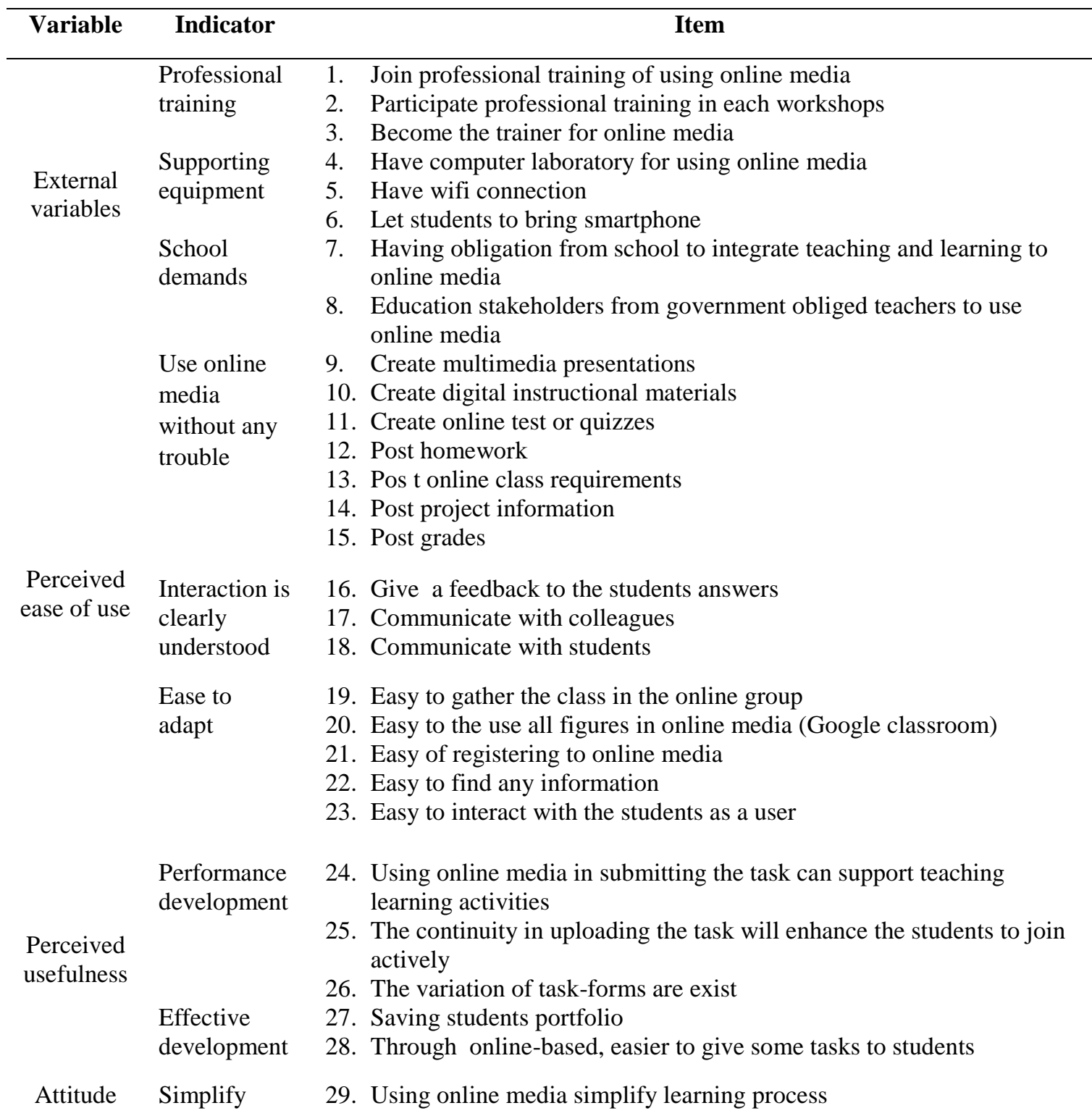




\begin{tabular}{|c|c|}
\hline working & 30. Able to monitor students progress \\
\hline process & 31. Can promote students learning \\
\hline & 32. Can promote students achievement \\
\hline Fancy using & 33. Interesting features \\
\hline the media & 34. Can promote students confidence \\
\hline & 35. Can promote students motivation \\
\hline & 36. Can make my lesson more interesting \\
\hline & 37. Can make my lesson more fun \\
\hline Helpful & 38. Feeling assisted with the features in online media \\
\hline features & 39. The features on online media let other users (students) to use it easily \\
\hline & 40. Providing students' exercise easily through tasks menus \\
\hline Use the & 41. Use the online media twice a month \\
\hline media & 42. Use the online media for submitting homework \\
\hline intensively & 43. Use online media to save students portfolios \\
\hline Duration of & 44. More than twice a month use online media \\
\hline $\begin{array}{l}\text { using online } \\
\text { media }\end{array}$ & $\begin{array}{l}\text { 45. Spending one whole meeting in the classroom teaching and learning } \\
\text { through online media }\end{array}$ \\
\hline Actual & 46. Use technologies in teaching and learning. \\
\hline $\begin{array}{l}\text { technology } \\
\text { use }\end{array}$ & 47. Use technology in my lesson regularly \\
\hline
\end{tabular}

\section{Data Analysis Procedure}

This study explored qualitatively the current condition of elementary teachers' acceptance and factual use of online media in teaching. The researcher classified each indicator qualitatively based on interview data reduction. A descriptive analysis was selected because an understanding of teacher technology acceptance, and integration in classroom practice was obtained (Yin, 2013).

\section{Participants}

The study was targeted to the teachers of the higher levels (4th-6th graders) of primary schools. The reason for the lower levels of primary school (1st-3rd graders) are having no integrated learning (purposeful sampling). The participants consisted of 30 teachers from four different schools in Serang City, Indonesia. There are 18 female and 12 male with an average age of $37(\mathrm{SD}=6.34)$ involved in this study. Places of research were taken from both private and government schools in Serang. The places are namely The State Elementary School of 02 Kota Serang and The State Elementary School of 11 Kota Serang as the representative of government schools. Besides that, for the private schools, they were represented by The $\mathrm{Al}$ Azhar Islamic Elementary School and Khalifah Islamic Integrated Elementary School.

\section{RESULTS AND DISCUSSION}

The data were taken from the teachers' answers consisting of external variables, perceived usefulness, perceived ease of use, behavioral intention use, and actual use.

\section{External Variables}

Based on the external variables result (figure.2) this research found that there is an intermediate professional background of teachers on online teaching. Some teachers (50-60\%) have experience in joining professional training on using online media. Some of them had the training for about 5 years ago in their bachelors study. Few of the participants were having independent training or workshop after actively working as teachers. Unfortunately, the participants have less (30\%) internet connection in the school. The limit of facilitation still made the high barrier of this section. Due to the regulation, the teachers also forbid the students to 
bring Smartphones to the school. Smartphones are still assumed as a destructor of the learning environment in the school. The participants thought that primary school students still had unstable management in controlling the use of technology. On the other hand there is a high demand to oblige teacher to implement the online media both from the educational stakeholders $(86.66 \%)$ and from school authorities (93.33\%) as impact of rapid development of technology. The obligation could be seen from the use of the internet system in national annual students' report and teachers professional monitoring.

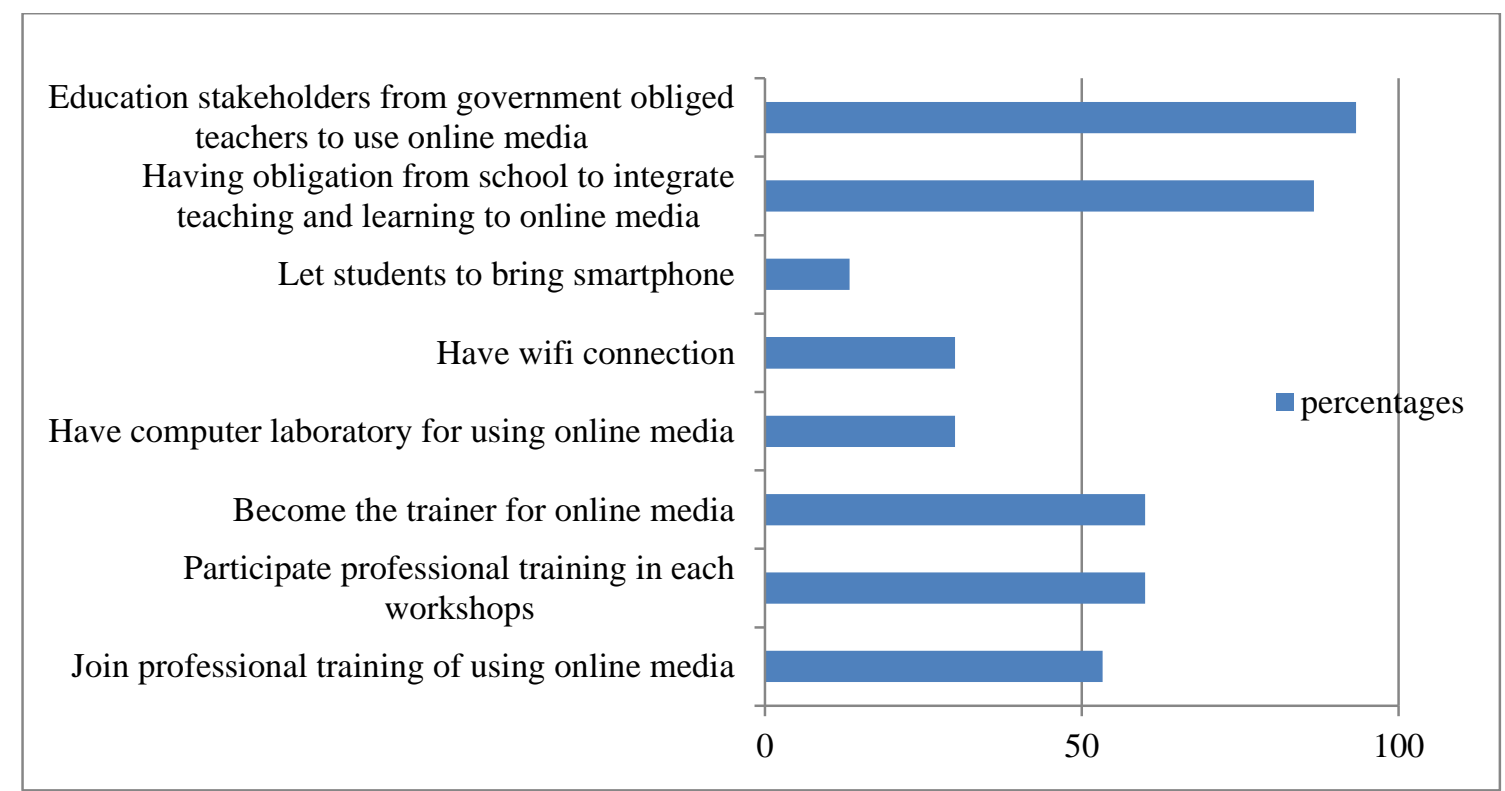

Figure 2. External Variables İtems Responses

The result can also be analyzed based on the school's operator. Based on the results of surveys which were conducted into two kinds of school, government schools and private schools, the researcher found various differences. Government schools in Serang never use online media by the reason having less external influences to support online media teaching. Although they got professional teaching from the education stakeholders, their participation was limited. Besides that, the schools' facilities are limited to using computers only in the school. Moreover, the students cannot bring their own Smartphone to the schools that add the challenges of using online media in the school. Therefore, private schools rarely use online media because the majority of their teaching and learning activities are held in the schools, so that they cannot be mentioned as heavy users. The facilities in the school that can be accessed in the computer lab are used for the ICT lesson, for the other lessons, using the facilities cannot be held continually using the facilities.

\section{Perceived The Ease of Use}

All of the items in the section were perceived positively by the respondents (figure.3). Creating digital multimedia, materials, quizzes, and posting complete online classes were familiar for them. They also showed positive experiences and beneficiaries on online learning to give feedback and communicate to the learning communities. The teacher felt the ease of use in gathering the class, optimizing figures, registering students, and finding information as well as interacting with students. 


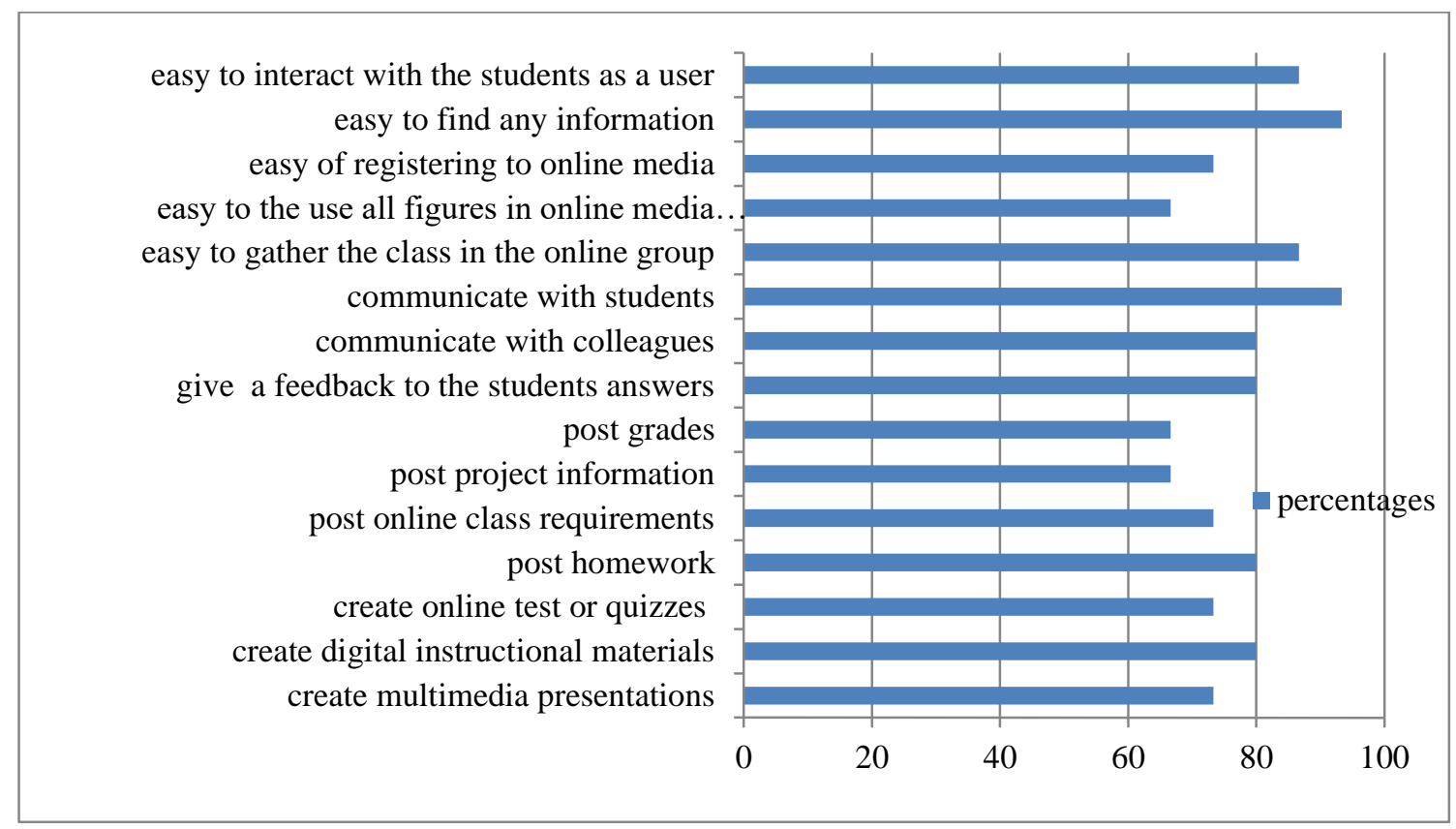

Figure 3. Perceived The Ease of Use İtems Responses

In the perceived ease of use, however, the teachers cannot apply online media in their teaching continuously, based on the training, the majority of them mentioned using online media is easy. Because they get used to having technology interaction every day, they have no trouble using the features in online media, such as Google form. Since they were well-trained, the participants felt easy to adapt and make interaction clearly through online media.

\section{Perceived of Usefulness}

The variable primarily concentrated on the teachers' perception on the use of instructional technologies in the future. Participants were asked pertaining about their reasons for online technology usage and perceptions toward online media usage. Online media were perceived helpful for giving and receiving students' tasks and engaging them to be active in the learning process. The digital features of online media also gave them the opportunity to save paper portfolios and apply various task-forms.

through online-based, easier to give some tasks to students

Saving students portfolio

The variation of task-forms are exist

The continuity in uploading the task will enhance the students to join actively

Using online media in submitting the task can support teaching learning activities

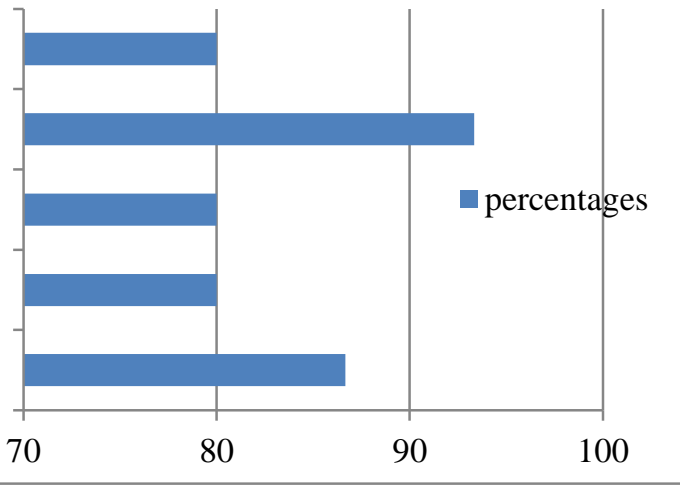

Figure 4. Perceived of Usefulness İtems Responses 
Based on the data, both of the schools, government and private schools have similar answers (figure.4). The indicators of performance development and effective development are based on their online media use. Even though the online media is rarely used and only in specific schools, both the performance development and effective development of online media still be drawn. They perceived to have developing performance and work effectiveness during the online learning implementation. In the prospective user, they also will feel the advance teaching effectiveness based on their knowledge or their colleagues' experience.

\section{Attitudes}

In the section of teachers' attitude (figure.5), researchers found that almost all the respondents had a positive attitude toward online learning. Online learning was perceived as a way to simplify the learning process. Unfortunately it seemed rather hard to monitor the students' learning progress since it takes a lot of time and support. The participants argue that online media was impactful in the process but indirect influences toward the learning achievement. The selecting pedagogical approach is still perceived as the main components influencing the students' achievement.

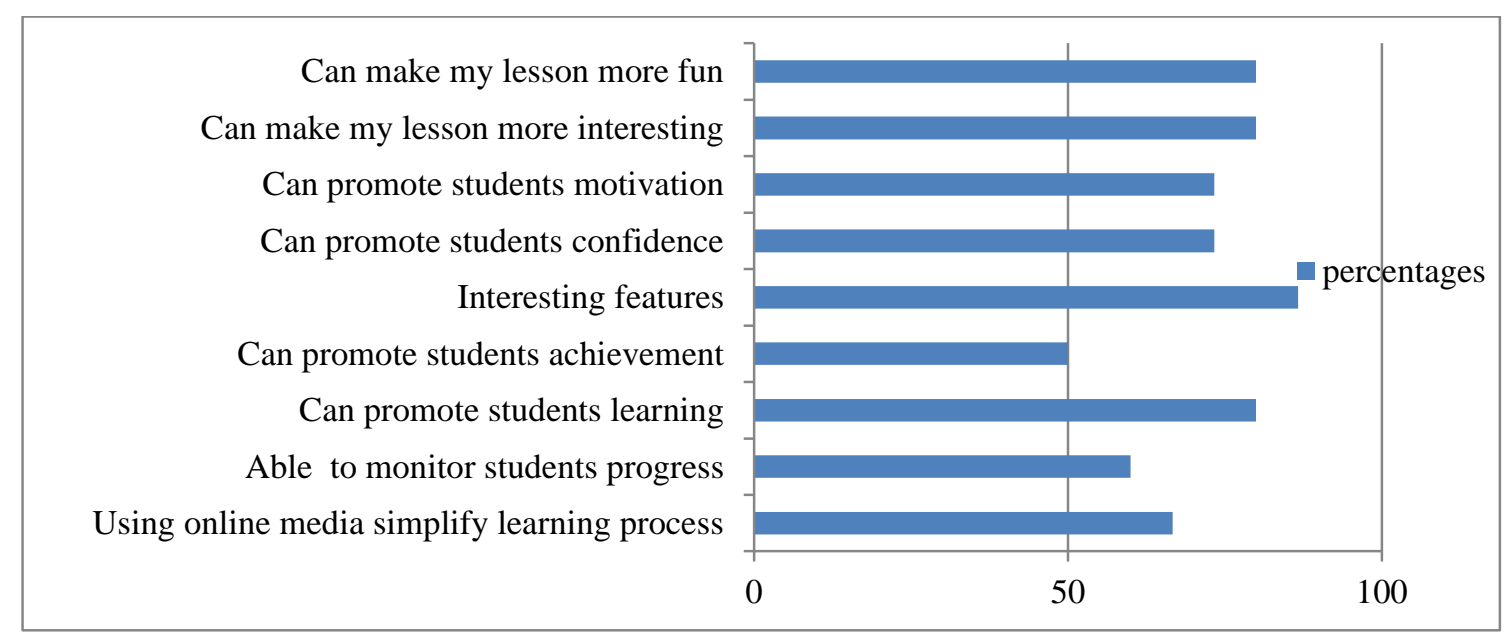

Figure 5. Attitudes İtems Responses

In the teachers' attitude towards online media, they mentioned teaching through online media is actually able to accelerate their teaching process as long as the schools facilitate the situations or let students fulfill their own equipment of Smartphone. They believe integrated learning through online media has interesting features that can promote students' confidence and motivation in learning. Besides that, they believe it can make their lessons more interesting and fun.

\section{Behavioral İntention to Use}

The behavioral intention of the participants showed the lack of online media use (figure.6) They have a lack of experience on practical use of online media in saving students portfolio, submitting homework. Furthermore, some of them stated that only once use online media during 5 years teaching experience. Some teachers had irregular usage of online media twice a month. However, they use only one type of media during the irregular usage. 
Use online media to save students portfolios

Use the online media for submitting homework

Use the online media twice a month

Providing students' exercise easily through tasks menus

The features on online media let other users (students) to use it easily

Feeling assisted with the features in online media

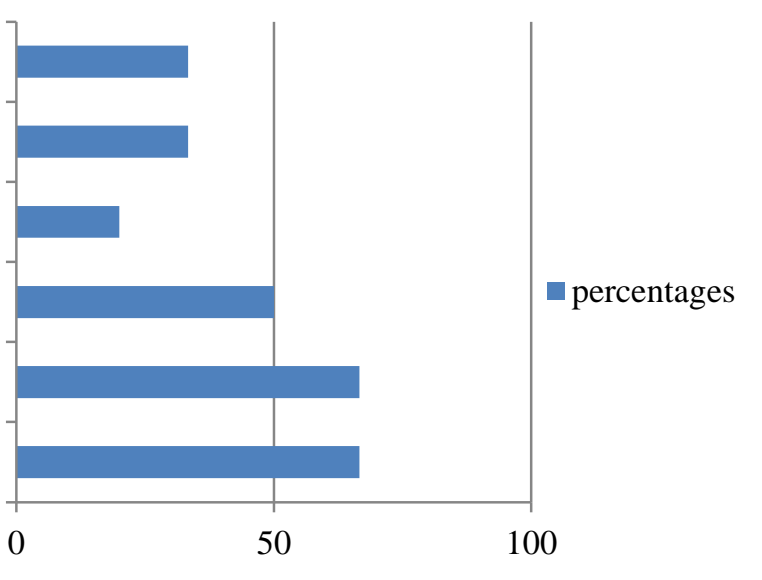

Figure 6. Behavioral İntention to Use İtems Responses

Since online media was not used intensively in the classrooms, the researchers found the teacher (from the private schools) used online media relatively according to the availability of using the provided facilities. The activities were rarely done because since it is lacking in accessing the supporting equipment, they tend to use general technology such as laptop and projector as teaching media. The other indicator of helpful features, the teachers cannot get the experiences of using online media in assisting their teaching.

\section{Actual Use}

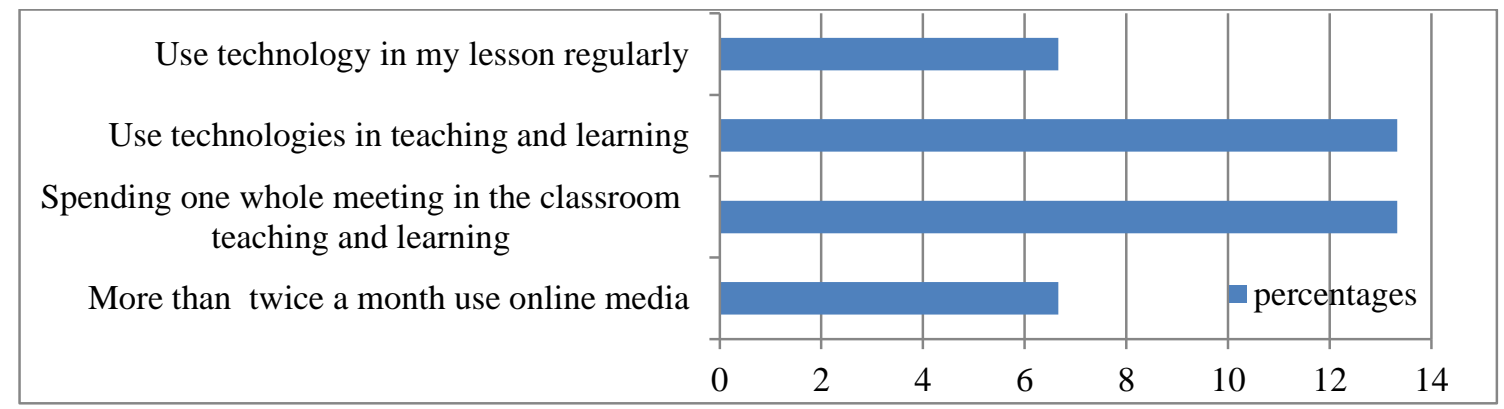

Figure 7. Actual use items responses

The last of TAM variables showed the participants' lack of factual use of online media (less than 20\%). A few respondents use online media for more than twice a month and spend the whole meeting fully online (figure.7). They also have limited experience of regular technology usage in teaching and learning. In this section, actual use of online media, the teachers mentioned that online media was used only a few times in the schools. They added in the activities of integrated learning, they did whole learning instructions through online media. Besides the duration, in the indicator of actual use of technology, the teachers prefer using other supporting technology which are affordable and can be used more often than online media. Kinds of integrated technology in the class that they tried to apply are power point presentation, listening through cassette or radio, presenting audiovisual through projector. 
In recent years there has been an increased amount of study addressing online learning as an alternative technique in the teaching services. Because these results have different dimensions, teachers' positive and negative perception of online media will be discussed. This study revealed the assumption that the rural school with his lack of technology support would face the challenges in using online learning. This research investigated the deeper reason of participants not to use online media.

In this investigation, as the main reason for not using online learning, participants stated supporting facilities were not unsure of possibilities offered by online learning. They sometimes felt that they could not find the relevance of online media in learning to their subject area. Even though they have preoccupied and had training on how to integrate online media into their teaching in order to recognize the possibilities new technology can bring.

Schools' supporting facilities was found to be one of the biggest barriers to using online media in teaching (Buabeng-Andoh, 2012). Some participants feel really enthusiastic but their enthusiasm is not going to last since lack of technological support made their proposal is not recognized and rewarded to some extent.

Most of the elementary teachers participating in the research said that they would consider using online media in learning in the future. Half of them highlighted the most important items that would foster them to use online media such as available and sustainable facilities support, opportunity for workshop and training for implementing online pedagogical practice (Machado \& Chung, 2015) and institutional support of policy on using online learning as well as incentives and reward for using innovative e-learning (Softić, 2015).

To promote teachers to improve their teaching with online media should enable them to engage them in familiar circumstances. Teachers should have been familiar with components that mostly use online learning (65\%), or blended learning (45\%) as an extension of their online classroom alternatives. By fostering the implementation of online media it will impact on adjusting learning to meet the recent students' needs and better learning achievement. Not only should students be better able to navigate a highly technological world, but the more fully integrated online technology into classroom instruction also indicates higher levels of student engagement in rural areas (Blanchard, et al., 2016).

The study suggested that increasing teacher online learning integration may be reached simply by giving them more access to technology. Online media availability and frequency were significantly more positive in areas which had more access to technology.

\section{CONCLUSIONS}

This study revealed the acceptance and use of online learning on six variables; external variables, perceived ease of use, perceived usefulness, attitude, behavioral intention use and actual use. Based on the analysis, the teachers' acceptance of using online media in the teaching and learning process are positive. The trouble in operating online media can be managed by their ability in applying technology.

Regarding the analysis, the teachers cannot use online media in teaching and learning appropriately. The analysis showed the majority of the problems in integrating teaching toward online media as an internet-based learning are caused by the lack supporting technology equipment. Besides that, the school rules are not fit with the government initiation of using online media in the school by prohibiting students fulfilling their integrated learning needs with smartphones or other internet connected devices.

One of the main limitations of the study is the limited scope of the study which is conducted only in Serang city, Banten province. The result may indicate a different number of factors were identified as well as recommendations for the issue on a larger scale. Additionally, this study was conducted in only one city in Indonesia; thus, it is suggested to conduct a study regarding various other contexts with changing features such as cities or towns in various regions across Indonesia. Further research is, thus, suggested to include classroom observations, 
focus group interviews with stakeholders such as teachers as well as families. Further research can also be conducted on a wider scale.

\section{REFERENCES}

Aljaraideh, Y., \& Bataineh, K. A. (2019). Jordanian students' barriers of utilizing online learning: A survey study. International Education Studies, 12(5), 99-108. https://doi.org/10.5539/ies.v12n5p99

Al-Suqri, M. N. (2014). Perceived usefulness, perceived ease-of-use and faculty acceptance of electronic books: An empirical investigation of Sultan Qaboos University, Oman. Library Review , 63, 4-5. https://doi.org/10.1108/LR-05-2013-0062

Amin, M., Rezaei, S., \& Abolghasemi, M. (2014). User satisfaction with mobile websites: The impact of perceived usefulness, perceived ease of use, and trust. Nankai Business Review International , 5 (3), 258-274. https://doi.org/10.1108/NBRI-01-2014-0005

Asiri, M. J., Mahmud, R. b., Bakar, K. A., \& Ayub, A. F. (2012). Factors influencing the use of learning management system in Saudi Arabian higher education: A theoretical framework. Higher Education Studies, 2(2), 125-137. https://doi.org/10.5539/hes.v2n2p125

Babić, S. (2012). Factors that influence academic teacher's acceptance of e-learning technology in blended learning environment. In E. Pontes, A. Silva, A. Guelfi, \& S. Takeo, ELearning-Organizational Infrastructure and Tools for Specific Areas (p. 9). In Tech Open.

Basak, S. K., Wotto, M., \& Belanger, P. (2018). E-learning, M-learning and D-learning: Conceptual definition and comparative analysis. E-Learning and Digital Media , 15 (4), 191-216. https://doi.org/10.1177/2042753018785180

Blanchard, M., LePrevost, C. E., Tolin, A. D., \& Guiterrez, K. S. (2016). Investigating technology-enhanced teacher professional development in rural, high-poverty middle schools. Sage Journals , 45 (3), 207-220. https://doi.org/10.3102/0013189X16644602

Buabeng-Andoh, C. (2012). Factors influencing teacher's adoption and integration of information and communication technology into teaching: a review of the literature. International Journal of Education and Development using Information and Communication Technology, 8 (1), 136-155.

Cheng, Y.-M., Lou, S.-J., Kuo, S.-H., \& Shih, R.-C. (2013). Investigating elementary school students' technology acceptance by applying digital game-based learning to environmental education. Australasian Journal of Educational Technology , 29 (1), 96110. https://doi.org/10.14742/ajet.65

Chipps, J., Kerr, J., Brysiewicz, P., \& Walters, F. (2015). A survey of university students' perceptions of learning management systems in a low-resource setting using a technology acceptance model. Computers, Informatics, Nursing , 33, 71-77. https://doi.org/10.1097/cin.0000000000000123

Chipps, J., Pimmer, C., Brysiewicz, P., Walters, F., Linxen, S., Ndebele, T., et al. (2015). Using mobile phones and social media to facilitate education and support for rural-based midwives in South Africa. Curationis, 38 (2), 1-8. https://doi.org/ 10.4102/curationis.v38i2.1500

Creswell, J. W. (2013). Qualitative inquiry \& research design (3rd ed.). Thousand Oaks, CA: Sage Publishing. 
Darling-Hammond, L., Flook, L., Cook-Harvey, C., Barron, B., \& Osher, D. (2020). Implications for educational practice of the science of learning and development. Applied Developmental Science, 24 (2), 97-140. https://doi.org/10.1080/10888691.2018.1537791

Davis, F. (1993). User acceptance of information technology: System characteristics, user perceptions, and behavioral impacts. International Man-Machine Studies , 38, 475-487. http://dx.doi.org/10.1006/imms.1993.1022

Davis, F., Bagozzi, R. P., \& Warsaw, P. R. (1989). User acceptance of computer technology: A comparison of two theoretical models. Management Science, 35 (8), 982-1002. https://doi.org/10.5555/2797314.2797319

Eaton, S. E. (2010). Global Trends in Language Learning in the Twenty-first Century. Calgary: Onate Press.

Faizi, R., El-Afia, A., \& Chiheb, R. (2013). Exploring the potential benefits of using social media in education. International Journal of Engineering Pedagogy , 3 (4), 5053.http://dx.doi.org/10.3991/ijep.v3i4.2836

Garcia, A., Abrego, J., \& Jauregui, J. (2019). Technologies frequently used by elementary principals. Universal Journal of Educational Research, 7(1), 95-105. https://doi.org/10.13189/ujer.2019.070113

Gellerstedt, M., Babaheidari, S. M., \& Svensson, L. (2018). A first step towards a model for teachers' adoption of ICT pedagogy in schools. Heliyon, 4, 10-17. https://doi.org/10.1016/j.heliyon.2018. e00786

Holden, H., Ozok, A., \& Rada, R. (2008). Technology use and acceptance in the classroom: Results from an exploratory survey study among secondary education teachers in the USA. Interactive Technology and Smart Education, 5(2), 113-134. https://doi.org/10.1108/17415650810880772

Jeffrey, D. A. (2015). Testing the Technology Acceptance Model 3 (TAM 3) with the inclusion of change fatigue and Overload, in the context of faculty from seventh day adventist universities : A revised model. Dissertations, 1581, 1-180.

Juhary, J. (2014). Perceived usefulness and ease of use of the learning management system as a learning tool. International Education Studies, 7(8), 23-24. https://doi.org/10.5539/ies.v7n8p23

Kanchanatanee, K., Suwanno, N., \& Jarenvongrayab, A. (2014). Effects of attitude toward using,perceived usefulness, perceived ease of use, and perceived compatibility on intention to use e-marketing. Journal of Management Research, 6(3), 1-13. https://doi.org/10.5296/jmr.v6i3.5573

Kats, Y. (2010). Learning Management System Technologies and Software Solutions for Online Teaching: Tools and Application. Hershey, PA: IGI Publishing.

Machado, L. J., \& Chung, C. (2015). Integrating technology: The principal's role and effect. International Education Studies , 8 (5), 43-53. http://dx.doi.org/10.5539/ies.v8n5p43

Malik, R. S. (2018). Educational challenges in 21st century and sustainable development. Journal of Sustainable Development Education and Research, 2(1), 9-20. https://doi.org/10.17509/jsder.v2i1.12266

Mayer, R. E., \& Moreno, R. (2007). A Cognitive Theory of Multimedia Learning: Implications for Design Principles. California: University of California.

Pimmer, C., Chipps, J., Brysiewicz, P., Walters, F., Linxen, S., \& Gröhbiel, U. (2016). Supervision on social media: Use and perception of Facebook as a research education tool 
in disadvantaged areas. International Review of Research in Open and Distributed Learning , 17 (5), 200-214. https://doi.org/10.19173/irrodl.v17i5.2547

Player-Koro, C. (2012). Factors influencing teachers' use of ICT in education . Education Inquiry , 3 (1), 93-108. https://doi.org/10.3402/edui.v3i1.22015

Redecker, C., \& Punie, Y. (2013). The future of learning 2025: Developing a vision for change. Future Learning , 1, 3-17. https://doi.org/10.7564/13-FULE12

Sadeghi, K., \& Dousti, M. (2013). The effect of length of exposure to CALL technology on young Iranian EFL learners' grammar gain . English Language Teaching , 6 (2), 14-26. https://doi.org/10.5539/elt.v6n2p14

Sayfouri, N. (2016). Evaluation of the learning management system using students' perceptions. Medical Journal of the Islamic Republic of Iran , 30, 1-10.

Scott, C. L. (2015). The Future of Learning 3: What kind of pedagogies for the 21st century? (ERF Working Papers Series, No. 15 ed.). Paris: UNESCO Education Research and Foresight.

Simuforosa, M. (2013). The impact of modern technology on the educational attainment. International Journal of Education and Research , 1 (9), 1-8.

Softić, S. K. (2015). Teacher's technology use and attitude towards e-learning in higher education. Proceedings of the European Distance and E-Learning Network 2015 Annual Conference (pp. 531-539). Barcelona: European Distance and E-Learning Network.

Teeroovengadum, V., Heeraman, N., \& Jugurnath, B. (2017). Examining the antecedents of ICT adoption in education using an Extended Technology Acceptance Model (TAM). International Journal of Education and Development using Information and Communication Technology, 13(3), 4-23. Retrieved June 2, 2020 from https://www.learntechlib.org/p/182155/.

Teo, T., \& Milutinovic, V. (2015). Modelling the intention to use technology for teaching mathematics among pre-service teachers in Serbia. Australasian Journal of Educational Technology , 31 (4), 363-380. https://doi.org/10.14742/ajet.1668

Varol, F. (2013). Elementary school teachers and teaching with technology. The Turkish Online Journal of Educational Technology, 12 (3), 85-90.

Weng, F., Yang, R.-J., Ho, H.-J., \& Su, H.-M. (2018). A TAM-based study of the attitude towards use intention of multimedia among school teachers. Applied System Innovation, $l$ (36), 1-9. https://doi.org/10.3390/asi1030036

Yin, R. (2013). Case study research: Design and methods (5th ed.). Thousand Oaks, CA: Sage. 